\title{
CORPORATE GOVERNANCE, OPINI GOING CONCERN, SUBSEQUENT EVENT DAN AUDIT REPORT LAG
}

\author{
Sigit Handoyo ${ }^{1 *}$, Nur Hasanah ${ }^{2}$ \\ 1,2 Prodi Akuntansi Fakultas Ekonomi Universitas Islam Indonesia \\ *Korespondensi: $963120101 @$ uii.ac.id
}

\begin{abstract}
Audit Report Lag is completion time of the annual financial audit statements from the date of company book closing up to the date of the audit report. This research represents empirical study to know influence of corporate governance, going concern opinion, and subsequent event toward Audit Report Lag.The populations of this research are all of manufacturing companies listed on Indonesia Stock Exchange in 2013. Samples of this research are 137 companies and the method of data analysis is using descriptive and doubled regression analysis. To obtain model of regression which representative is hence conducted by test of classic assumption. The result of descriptive statistic indicate that mean of an audit report lag in 2013 is 76,0146 days. The result of this research shows that the size of the board of directors, audit opinion and going concern opinion significant effect on Audit Report Lag. Furthermore, Independence board of directors, audit committee independence and subsequent event have not influence toward Audit Report Lag.
\end{abstract}

Keywords : Audit Report Lag, Corporate Governance, Going Concern Opinion and Subsequent Event.

\begin{abstract}
ABSTRAK
Laporan Audit Lag adalah waktu penyelesaian laporan audit keuangan tahunan dari tanggal penutupan buku perusahaan sampai dengan tanggal laporan audit. Penelitian ini merupakan penelitian empiris untuk mengetahui pengaruh corporate governance, going concern opinion, dan kejadian selanjutnya terhadap Laporan Audit Lag. Populasi dalam penelitian ini adalah seluruh perusahaan manufaktur yang terdaftar di Bursa Efek Indonesia pada tahun 2013. Sampel dalam penelitian ini adalah 137 perusahaan dan Metode analisis data menggunakan analisis regresi berganda dan dua kali lipat. Untuk mendapatkan model regresi yang representatif dilakukan dengan uji asumsi klasik. Hasil statistik deskriptif menunjukkan bahwa rata rata keterlambatan laporan audit pada tahun 2013 adalah 76.0146 hari. Hasil penelitian ini menunjukkan bahwa ukuran dewan direksi, opini audit dan going concern opini berpengaruh signifikan terhadap Laporan Audit Lag. Selanjutnya, dewan direksi Independence, independensi komite audit dan kejadian selanjutnya tidak berpengaruh terhadap Laporan Audit Lag.
\end{abstract}

Kata Kunci : Audit Report Lag, Corporate Governance, Opini Going Concern dan Subsequent Event.

\section{PENDAHULUAN}

Laporan keuangan berperan penting dalam penilaian kinerja perusahaan serta penting untuk mengambil keputusan, sehingga harus disusun sedemikian rupa agar dapat memenuhi kebutuhan seluruh pihak yang membutuhkan seperti kreditor, investor, pemerintah, masyarakat dan pihakpihak lain. Menurut Pernyataan Standar Akuntansi Keuangan (PSAK) 2010, tujuan dari laporan keuangan adalah untuk menyediakan informasi yang menyangkut posisi keuangan, kinerja, serta perubahan posisi keuangan suatu perusahaan yang bermanfaat bagi sejumlah besar pengguna. Tujuan dari pemeriksaan laporan keuangan oleh auditor independen yaitu untuk menilai kewajaran penyajian laporan keuangan yang tentunya memerlukan waktu yang tidak singkat. Apabila laporan keuangan tidak disajikan tepat waktu maka laporan keuangan tersebut akan 
kehilangan nilai informasinya, karena tidak tersedia saat pemakai laporan keuangan membutuhkan untuk pertimbangan dalam pengambilan keputusan.

Dalam Untuk menghasilkan laporan keuangan yang memberikan informasi yang relevan, terdapat beberapa kendala, salah satunya adalah ketepatan waktu dalam penyampaian laporan keuangan yang dipublikasikan (Wijaya, 2012) . Tertundanya penyampaian laporan keuangan dapat dikaitkan dan dipengaruhi oleh jangka waktu pelaporan audit (audit report lag). Menurut Lianto dan Kusuma (2010) menjelaskan audit report lag adalah rentang waktu penyelesaian pelaksanaan audit laporan keuangan tahunan yaitu sejak tanggal tutup buku perusahaan sampai tanggal yang tertera pada laporan auditor independen.

Di Indonesia, batas waktu penerbitan laporan keuangan perusahaan publik diatur oleh Badan Pengawas Pasar Modal (Bapepam). Berdasarkan peraturan Bapepam No.X.K.2, lampiran keputusan ketua Bapepam Nomor: Kep/346/BL/2011 mengenai Kewajiban Penyampaian Laporan Keuangan Berkala, Bapepam mewajibkan setiap perusahaan publik yang terdaftar di Pasar Modal wajib menyampaikan laporan keuangan tahunan disertai dengan laporan auditor independen kepada Bapepam selambat-lambatnya akhir bulan ketiga (90 hari) setelah tanggal laporan keuangan tahunan.

Adanya entitas bisnis merupakan ciri dari sebuah lingkungan ekonomi dalam jangka panjang yang bertujuan untuk mempertahankan kelangsungan hidup usahanya melalui asumsi going concern. Asumsi going concern berarti suatu badan usaha dianggap akan mampu mempertahankan kegiatan usahanya dalam jangka waktu panjang dan tidak akan dilikuidasi dalam jangka waktu pendek. Going concern merupakan salah satu bagian dari opini audit wajar dengan bahasa penjelasan.

Rachmawati (2008), menyatakan perusahaan yang mengalami rugi cenderung memerlukan auditor untuk memulai proses pengauditan lebih lambat dari biasanya. Penundaan pengeluaran laporan audit dilakukan dengan harapan perusahaan dapat memecahkan masalah keuangannya dan menghindari opini going concern. Opini audit going concern merupakan opini yang dikeluarkan auditor untuk memastikan apakah perusahaan dapat mempertahankan kelangsungan hidupnya (IAI, 2001 : SA Seksi 341.02).

Penelitian mengenai audit report lag di Indonesia telah dilakukan oleh beberapa peneliti diantaranya oleh Naimi (2010), Wijaya (2012) dan Wardhani dan Surya (2013) melakukan penelitian yang berkaitan dengan pengaruh corporate governance terhadap audit report lag. Akan tetapi mempunyai hasil yang berbeda-beda. Naimi (2010) dan Wardhani dan Surya (2013) mempunyai temuan yang sama yaitu komisaris independen tidak berpengaruh terhadap audit report lag sedangkan variable corporate governance lainya berpengaruh terhadap audit report lag. Penelitian lainnya juga dilakukan oleh Setyorini (2008) dan Cecile (2010) yang menemukan 
bahwa opini audit berpengaruh terhadap audit report lag akan tetapi ukuran dan opini going concern tidak berpengaruh.

Dalam laporan keuangan historis yang menyajikan posisi keuangan pada tanggal tertentu, perubahan ekuitas, serta arus kas untuk periode yang berakhir pada tanggal tersebut, sehingga sangat berhubungan dengan penerbitan laporan auditor independen. Namun, ada peristiwa atau transaksi yang kadang-kadang terjadi sesudah tanggal tersebut tetapi sebelum diterbitkannya laporan keuangan dan laporan audit, yang mempunyai dampak material terhadap laporan keuangan, sehingga memerlukan penyesuaian atau pengungkapan dalam laporan-laporan tersebut. Transaksi atau kejadian ini untuk selanjutnya disebut subsequent events. Oleh karena itu, dengan adanya subsequent events dikhawatirkan akan menyebabkan audit report lag lebih lama. Sebagaimana penjelasan tersebut, maka pene;iti berpendapat perlu untuk melakukan sebuah penelitian lebih mendalam mengenai audit report lag terutama dengan memasukkan unsur subsequent event sebagai variable independennya selain variable-variabel lainnya sebagaimana pernah dilakukan dalam penelitian-penelitian sebelumnya.

\section{TINJAUAN TEORI}

\subsection{Teori Agensi}

Jensen dan Meckling (1976) menjelaskan hubungan keagenan dalam teori agensi bahwa didalam perusahaan terdapat hubungan kontrak antara agen (manajemen) dengan principal (pemilik). Teori agensi merupakan dasar yang digunakan perusahaan untuk memahami corporate governance. Dengan demikian pihak prinsipal adalah pihak yang memberikan mandat kepada pihak lain yaitu agen untuk melakukan segala kegiatan atas nama prinsipal dalam kapasitasnya sebagai pengambilan keputusan.

Agent memiliki lebih banyak informasi tentang perusahaan dibandingkan principal.Permasalahan yang timbul akibat adanya perbedaan kepentingan antara principal dan agent disebut dengan agency problems. Salah satu penyebab agency problems adalah adanya asymmetric information. Asymmetric information adalah ketidaksinambungan informasi yang dimiliki principal dan agent, ketika principal tidak memiliki informasi yang cukup tentang kinerja agen sebaliknya, agent memiliki lebih banyak informasi mengenai kapasitas diri, lingkungan kerja dan perusahaan secara keseluruhan (Wijaya, 2012). gency theory dapat berupa kontrak kerja yang mengatur proporsi hak dan kewajiban masing-masing pihak dengan memaksimalkan utilitas. Melalui hak yang dimiliki para pemangku kepentingan, pihak yang bersangkutan berusaha untuk mengontrol perusahaan. Terutama mengenai pendanaan untuk memajukan pertumbuhan perusahaan, pada masing-masing pihak berusaha untuk mengeluarkan pendapatnya agar dapat memperoleh keuntungan yang optimal. Dalam hal ini manajemenlah yang paling banyak memiliki informasi mengenai keadaan perusahaan sehingga memiliki kesempatan paling 
besar untuk mengelola keadaan perusahaan, hal ini yang memicu adanya agency problem yang dapat diselesaikan dengan agency costt (Hariani,2014).

Berbagai pemikiran mengenai corporate governance berkembang dengan bertumpu pada teori agensi, dimana pengelolaan perusahaan harus diawasi dan dikendalikan untuk memastikan bahwa pengelolaan dilakukan dengan penuh kepatuhan kepada peraturan dan ketentuan yang berlaku (OECD, 2004) . Jadi, teori agensi ini yang mendasari praktek corporate governance. Dengan adanya praktek corporate governance ini diharapakan tidak terjadi kecurangan dalam laporan keuangan yang disusun oleh manajemen yang dapat mengakibatkan audit report lag.

\subsection{Corporate Governance}

Monks \& Minow (2011) menyatakan bahwa Corporate Governance (CG) merupakan tata kelola perusahaan yang menjelaskan hubungan antara berbagai partisipan dalam perusahaan yang menentukan arah dan kinerja perusahaan. Di Indonesia isu mengenai CG mulai mengemuka setelah krisis berkepanjangan pada tahun 1998. Lemahnya CG yang diterapkan oleh perusahaan berakibat lamanya proses perbaikan di Indonesia. Sejak itulah, investor maupun pemerintah mulai memberikan perhatian dalam praktek Corporate Governance.

Porter (1991) menyatakan bahwa alasan mengapa perusahaan sukses atau gagal mungkin lebih disebabkan oleh strategi yang diterapkan oleh perusahaan. Kesuksesan suatu perusahaan banyak ditentukan oleh karakteristik strategis dan manajerial perusahaan tersebut. Strategi tersebut diantaranya dapat juga mencakup strategi penerapan sistem Good Corporate Governance(GCG) dalam perusahaan. Struktur GCG dalam suatu perusahaan bisa jadi dapat menentukan sukses tidaknya suatu perusahaan sehingga sangat menentukan nilai serta tingkat kesehatan perusahaan.

Corporate Governance biasanya mengacu pada sekumpulan mekanisme yang mempengaruhi keputusan yang akan diambil oleh manajer ketika ada pemisahan antara kepemilikan dan pengendalian. Beberapa dari pengendalian ini terletak pada fungsi dari dewan direksi, pemegang saham institusional, dan pengendalian dari mekanisme pasar (Larcker et al. 2005). Blair (1995) mendefinisikan Corporate Governance sebagai keseluruhan set aransemen legal, kebudayaan, dan institusional yang menentukanapa yang dapat dilakukan oleh perusahaan publik, yang berkaitandengansiapa yang mengendalikan,bagaimana pengendalian dilakukan,dan bagaimana risiko dan imbal hasil saham dari aktivitas-aktivitas yang dilakukan oleh perusahaan tersebut dialokasikan (Darmawati, 2003).

\subsection{Going Concern Opinion}

Salah satu asumsi yang dipakai dalam menyusun laporan keuangan adalah asumsi going concern. Asumsi ini mengharuskan entitas bisnis secara operasional memiliki kemampuan untuk mempertahankan kelangsungan hidupnya atau going concern. Hany et. al.(2003) menyatakan bahwa asumsi going concern berarti suatu badan usaha dianggap akan mampu mempertahankan kegiatan usahanya dalam jangka waktu panjang dan tidak akan dilikuidasi dalam jangka waktu 
pendek. Terkait dengan opini auditor, perusahaan yang menerima opini selain unqualified opinion memiliki audit report lag yang lebih lama dibandingkan yang menerima unqualified opinion. Lamanya audit report lag yang dialami karena kemungkinan munculnya konflik antara auditor dan perusahaan yang dapat berkontribusi pada penundanaan penerbitan laporan keuangan.

Laporan auditor yang menunjukkan opini going concern memerlukan evaluasi secara eksplisit terhadap kemungkinan kelangsungan hidup perusahaan dalam setiap audit. Jadi, adanya kecenderungan penundaan dalam memulai proses audit. Sehingga dalam penentuan opini going concern, auditor dapat mengidentifikasi informasi mengenai kondisi atau peristiwa tertentu, jika dalam perimbangan menunjukkan adanya keraguan besar tentang kemampuan entitas dalam mempertahankan kelangsungan hidupnya dalam jangka waktu tertentu. Pemberian opini going concern oleh auditor juga tidak terlepas dari opini audit yang diberikan tahun sebelumnya, karena kegiatan usaha pada suatu perusahaan untuk tahun tertentu tidak terlepas dari keadaan yang terjadi pada tahun sebelumnya (Cecile, 2010) .

\subsection{Subsequent Event}

Subsequent Event adalah peristiwa atau transaksi yang terjadi setelah tanggal neraca tetapi sebelum diterbitkannya laporan audit, yang mempunyai akibat yang material terhadap laporan keuangan, sehingga memerlukan penyesuaian atau pengungkapan dalam laporan tersebut. Didalam proses audit terdapat subsequent event yaitu proses penelaah transaksi-transaksi setelah tanggal neraca untuk mengevaluasi jumlah yang material dan peristiwa-peristiwa yang penting atau luar biasa sampai dengan tanggal selesainya pekerjaan lapangan audit. Menurut PSAK Nomor 8 Tahun 2010, Peristiwa setelah periode pelaporan (subsequent event) adalah peristiwa, baik yang menguntungkan (favourable) atau tidak menguntungkan (unfavourable), yang terjadi di antara akhir periode pelaporan dan tanggal laporan keuangan diotorisasi untuk terbit.

Subsequent Event (peristiwa kemudian) yang perlu diungkapkan dalam laporan keuangan, dengan kriteria sebagai berikut; (i) Jumlahnya material (ii) Merupakan peristiwa yang penting dan bersifat luar biasa (iii) Terjadi dalam periode sejak tanggal neraca sampai dengan tanggal selesainya pekerjaan lapangan audit.

Ada 2 jenis subsequent event (peristiwa kemudian) yaitu;

1) Subsequent Events yang memerlukan penyesuaian dalam laporan keuangan.

Subsequent events ini mengharuskan adanya penyesuaian terhadap laporan keuangan apabila telah ada pada tanggal neraca (existed at the balance sheet date) serta mempengaruhi kewajaran penyajian laporan keungan.

2) Subsequent Event yang memerlukan Pengungkapan (disclosure) dalam laporan keuangan. Syaratnya, sudah terdapat bukti/informasi mengenai kondisi yang belum terjadi pada tanggal neraca, tetapi memiliki pengaruh signifikan sehingga memerlukan pengungkapan.

Apabila terdapat subsequent event yang memiliki dampak langsung terhadap laporan keuangan maka auditor wajib mengusulkan adjustment terhadap laporan keuangan klien, jika 
subsequent event tidak mempunyai pengaruh langsung terhadap laporan keuangan maka memerlukan catatan kaki di dalam laporan keuangan klien, hal tersebutlah yangmungkin dapat menyebabkan adanya audit report lag lebih lama.

\subsection{Audit Report Lag}

Wardhani dan Surya (2013) menyatakan bahwa audit report lag adalah jangka waktu antara tanggal tahun buku perusahaan berakhir sampai dengan tanggal laporan audit. Perbedaan waktu antara tanggal laporan keuangan dengan tanggal laporan auditor independen mengindikasikan tentang lamanya waktu penyelesaian audit yang dilakukan oleh auditor.

Audit report lag yaitu jumlah hari antara akhir periode akuntansi sampai dikeluarkannya laporan audit. Audit reporting lag didefinisikan sebagai selisih waktu antara berakhirnya tahun fiskal dengan tanggal diterbitkannya laporan audit (Carslaw dan Kaplan, 1991). Ketepatan waktu penerbitan laporan keuangan auditan sangat penting khususnya untuk perusahaan-perusahaan publik yang menggunakan pasar modal sebagai salah satu sumber pendanaan

Semakin panjang suatu audit report lag, maka akan memberikandampak buruk bagi perusahaan. Lamanya waktu penyelesaian proses audit (audit report lag) akan mempengaruhi ketepatan waktu dalam publikasi informasi laporan keuangan auditan. IAI (2010) menyatakan bahwa jika terdapat penundaan yang tidak semestinya dalam pelaporan, maka informasi yang dihasilkan akan kehilangan relevansinya. Ketepatan waktu menunjukan laporan keuangan disajikan dalam kurun waktu teratur, untuk memperlihatkan perubahan keadaan perusahaan yang mungkin akan mempengaruhi pemikiran jangka panjang investor dan keputusan pemakainya (Wijaya 2012).

\subsection{Pengaruh Ukuran Dewan Komisaris terhadap Audit Report Lag}

Anggota komisaris mempunyai fungsi utama yaitu monitoring kinerja direksi sebagai pihak yang mengelola operasional perusahaan. Jumlah komisaris yang besar menguntungkan perusahaan dari sudut pandang resources dependence (Goodstein, Gautam, Boeker 1994). Semakin bertambahnya komisaris dalam suatu perusahaan maka fungsi monitoring terhadap kinerja direksi akan semakin dijalankan atau ditingkatkan seiring dengan semakin banyaknya komisaris yang melakukan pengawasan. Sehingga dengan semakin meningkatnya fungsi monitoring yang dijalankan komisaris tersebut maka kemungkinan perusahaan mengalami kesulitan keuangan akan semakin mengecil sehingga mampu memperpendek Audit Report Lag.

H1: Ukuran Dewan Komisaris berpengaruh negatif terhadap Audit Report Lag.

\subsection{Pengaruh Komisaris Independen terhadap Audit Report Lag}

Efektivitas komisaris dalam menyeimbangkan kekuatan CEO tersebut sangat dipengaruhi oleh tingkat independensi dari dewan komisaris tersebut (Wardhani, 2007)., Dewan yang aktif, 
berwawasan luas, dan independen sangat diperlukan untuk memastikan standar tata kelola perusahaan yang terbaik (Barton dan Wong, 2006). Sehingga dengan jumlah komisaris independen yang banyak diharapkan dapat menjamin bahwa mekanisme berjalan efektif dan sesuai dengan peraturan perundang-undangan sehingga akan memperpendek Audit Report Lag.

H2: Komisaris Independen berpengaruh negatif terhadap Audit Report Lag

\subsection{Pengaruh Komite Audit Independen terhadap Audit Report Lag}

Menurut Kirk, (2000) bahwa salah satu tujuan dari komite audit adalah untuk memberikan ulasan objektif tentang informasi keuangan, dan Komite Audit Independen dapat berkontribusi terhadap kualitas pelaporan keuangan. Dengan kata lain semakin banyak pihak independen dalam pengawasan maka diharapkan semakin efektif pengawasan yang terjadi, dengan begitu dapat meminimalisir kesalahan yang terjadi sehingga diharapkan mempersingakat audit report lag. Menurut Wardhani dan Surya (2013) Semakin banyak pihak independen dalam pengawasan maka diharapkan semakin efektif pengawasan yang terjadi, dengan begitu dapat meminimalisir kesalahan yang terjadi sehingga diharapkan mempersingkat audit report lag.

H3: Komite Audit Independen berpengaruh negatif terhadap Audit Report Lag

\subsection{Pengaruh Jenis Opini Auditor terhadap Audit Report Lag}

Setyorini (2008) menyatakan bahwa auditor akan mengeluarkan kualifikasi laporan audit, jika dalam menjalankan auditnya gagal mengkonfirmasikan kepatuhan klien terhadap peraturan yang berlaku. Pendapat Auditor dalam penelitian ini dibedakan menjadi dua, yaitu Standart Opinion (unqualified opinion) dan Non Standart Opinion (selain unqualified opinion). Pemberian non standart opinion atas laporan keuangan diperkirakan akan memperlambat proses pengauditan sebab auditor akan memerlukan lebih banyak bahan bukti dan pengujian untuk memperkuat pernyataannya bahwa laporan keuangan perusahaan tersebut tidak memenuhi syarat wajar tanpa pengecualian. Perusahaan yang memperoleh opini selain unqualified opinion akan membutuhkan waktu penyelesaian audit yang lebih panjang daripada perusahaan yang memperoleh opini unqualified. Karena menunjukkan adanya kecenderungan oleh pihak manajemen perusahaan untuk menunda penyampaian laporan keuangan kepada publik untuk mengantisipasi adanya sentimen negatif di pasar berkaitan dengan kinerja perusahaan. Oleh karena itu, bila perusahaan memperoleh opini selain unqualified opininion maka akan memperpanjang Audit Report Lag.

H4: Jenis opini yang diberikan oleh auditor berpengaruh negatif terhadap audit report lag

\subsection{Pengaruh Opini Going Concern terhadap Audit Report Lag}

Salah satu asumsi yang dipakai dalam menyusun laporan keuangan adalah asumsi going concern. Pemberian opini going concern oleh auditor juga tidak terlepas dari opini audit yang diberikan tahun sebelumnya, karena kegiatan usaha pada suatu perusahaan untuk tahun tertentu tidak terlepas dari keadaan yang terjadi pada tahun sebelumnya (Cecile, 2010). Laporan auditor yang menunjukkan opini going concern memerlukan evaluasi secara eksplisit terhadap 
kemungkinan kelangsungan hidup perusahaan dalam setiap audit. Jadi, adanya kecenderungan penundaan dalam memulai proses audit. Sehingga dalam penentuan opini going concern, auditor dapat mengidentifikasi informasi mengenai kondisi atau peristiwa tertentu, jika dalam perimbangan menunjukkan adanya keraguan besar tentang kemampuan entitas dalam mempertahankan kelangsungan hidupnya dalam jangka waktu tertentu oleh karena itu Audit Report Lag akan semakin lama.

H5: Opini Going Concern berpengaruh positif terhadap Audit Report Lag

\subsection{Pengaruh Subsequent Event terhadap Audit Report Lag}

Subsequent event merupakan sejumlah transaksi atau beberapa peristiwa yang terjadi setelah tanggal neraca tetapi sebelum diterbitkannya laporan audit yang mempunyai akibat yang material terhadap laporan keuangan dan memerlukan penyesuaian atau pengungkapan dalam laporan tersebut. Penelaahan subsequent event perlu dilakukan oleh auditor untuk menentukan apakah terjadi sesuatu yang mempengaruhi penilaian atau pengungkapan atas laporan keuangan yang sedang diaudit. Apabila terdapat subsequent event yang memiliki dampak langsung terhadap laporan keuangan maka auditor wajib mengusulkan adjustment terhadap laporan keuangan klien, jika subsequent event tidak mempunyai pengaruh langsung terhadap laporan keuangan maka memerlukan catatan kaki di dalam laporan keuangan klien, hal tersebutlah yang mungkin dapat menyebabkan adanya audit report lag lebih lama.

H6: Subsequent Events berpengaruh posistif terhadap Audit Report Lag

\section{METODE}

Populasi dalam penelitian ini adalah perusahaan-perusahaan manufaktur yang terdaftar di Bursa Efek Indonesia (BEI), sedangkan sampel pada penelitian ini menggunakan teknik pengambilan sampel purposive sampling yaitu teknik pengambilan sampel dengan kriteria tertentu. Kriteria pengambilan sampel adalah sebagai berikut: (i) Sampel adalah perusahaan manufaktur yang terdaftar di BEI tahun 2013, tidak mengalami delisting, (ii) menerbitkan laporan keuangan tahunan pada tahun 2013 dan komponen laporan keuangan yang diperlukan, (iii) menerbitkan laporan auditor independen, (iv) Memiliki data yang dibutuhkan dalam penelitian ini.

\subsection{Definisi Operasional}

\subsubsection{Audit Report Lag}

Variabel dependen dalam penelitian ini adalah audit report lag yaitu periode waktu antara akhir tahun fiskal dan tanggal laporan audit perusahaan. Dapat diartikan juga sebagai jangka waktu antara tanggal penutupan tahun buku sampai dengan tanggal ditandatanganinya laporan auditor independen. Variabel ini diukur secara kuantitatif dalam jumlah hari.

\subsubsection{Ukuran Dewan Komisaris}


Variabel ini diukur dari proporsi anggota dewan komisaris dalam perusahaan terkait. Data untuk variabel ini diperoleh dari annual report perusahaan.

\subsubsection{Komisaris Independen}

Menurut Wardhani dan Surya (2013), adanya komisaris independen diyakini dapat melindungi kepentingan seluruh pemegang saham.Cara mengukur variabel ini adalah dengan melihat proporsi jumlah dewan komisaris independendibandingkan dengan jumlah keseluruhan anggota dewan. Data untuk variabel ini diperoleh dari laporan tahunan perusahaan.

\subsubsection{Komite Audit Independen}

Variabel ini diukur dari proporsi anggota komite audit non-komisaris independen dengan seluruh anggota komite audit. Data untuk variabel ini diperoleh dari laporan tahunan perusahaan.

\subsubsection{Jenis Opini Auditor}

Jenis opini auditor dalam penelitian ini diklasifikasikan menjadi dua, yaitu unqualified opinion dan selain unqualified opinion. Untuk unqualified opinion diberi nilai 1, sedangkan untuk selain unqualified opinion diberi nilai 0 .

\subsubsection{Opini Going Concern}

Opini audit going concern adalah opini yang dikeluarkan oleh auditor untuk mengevaluasi apakah ada kesangsian tentang kemampuan perusahaan untuk mempertahankan kelangsungan hidupnya (IAI, 2001). Jika perusahaan mendapat opini going concern maka diberi nilai 1, dan sebaliknya jika tidak mendapat opini going concern maka diberi nilai 0 .

\subsubsection{Subsequent Event}

Subsequent Event merupakan peristiwa-peristiwa atau transaksi-transaksi yang terjadi setelah tanggal neraca tetapi sebelum diterbitkannya laporan audit yang berdampak material terhadap laporan keuangan perusahaan. Subsequent Events berupa catatan kaki yang memerlukan pengungkapan atau memerlukan penyesuaian. Dalam variabel penelitian ini yang dimaksudkan adalah subsequent events yang berupa catatan kaki yang memerlukan pengungkapan dalam catatan laporan keuangan.

Dalam penelitian ini, Jenis data yang digunakan adalah data dokumenter, sedangkan sumber data dalam penelitian ini adalah data sekunder yang berupa annual report dan laporan keuangan auditan perusahaan dan tanggal laporan auditor Independen yang terdaftar di Bursa Efek Indonesia (BEI) pada tahun 2013. Data perusahaanjuga dapat diakses dari website www.idx.co.id atau diperoleh dari pojok Bursa Efek Jakarta Universitas Islam indonesia serta Pusat Referensi Pasar Modal dan Indonesian Capital Market Directory (ICMD).

Berdasarkan hipotesis dalam penelitian ini, metode analisis data yang digunakan adalah metode analisis regresi berganda. Berikut persamaan regresi penelitian:

$\mathrm{ARL}=\beta 0+\beta 1 \mathrm{X} 1+\beta 2 \mathrm{X} 2+\beta 3 \mathrm{X} 3+\beta 4 \mathrm{X} 4+\beta 5 \mathrm{X} 5+\beta 6 \mathrm{X} 6+\varepsilon$

Dimana: 
$\beta 0=$ Konstanta

ARL = Audit report lag

$\mathrm{X} 1=$ Ukuran Dewan Komisaris

$\mathrm{X} 2=$ Proporsi Komisaris Independen

X3 = Komite Audit Independen

$\mathrm{X} 4=$ Jenis Opini yang diberikan oleh auditor

X5 = Opini Going Concern

X6 $=$ Subsequent Events

$\varepsilon=$ Error

\section{HASIL DAN PEMBAHASAN}

\subsection{Analisis Statistik Deskriptif}

Populasi yang digunakan dalam penelitian adalah seluruh perusahaan manufaktur yang terdaftar di Bursa Efek Indonesia tahun 2013 yang berjumlah 137 perusahaan. Sampel perusahaan tersebut kemudian dipilih dengan menggunakan purposive sampling. Setelah dilakukan seleksi pemilihan sampel sesuai kriteria yang telah ditentukan maka diperoleh 137 perusahaan yang memenuhi kriteria sampel. Maka kesimpulan yang dapat diambil dari hasil analisis statistik deskriptif dalam penelitian ini adalah Nilai minimum audit report lag adalah sebesar 45 sedangkan nilai maksimum audit report lag adalah sebesar 105. Nilai rata-rata audit report lag tahun 2013 adalah sebesar 76,0146 hari dengan standar deviasi sebesar 12,61826.

Nilai minimum ukuran dewan komisaris adalah sebesar 1 sedangkan nilai maksimum ukuran dewan komisaris adalah sebesar 7. Nilai rata-rata ukuran dewan komisaris tahun 2013 adalah sebesar 2,8102 dengan nilai standar deviasi sebesar 1,19147.

Nilai minimum komisaris independen sebesar 0 sedangkan nilai maksimum komisaris independen adalah sebesar 1. Nilai rata-rata komisaris independen perusahaan tahun 2013 adalah sebesar 0,5322 dengan standar deviasi sebesar 0,23874.

Nilai minimum komite audit sebesar 2 sedangkan nilai maksimum komite audit sebesar 5. Nilai rata-rata komite audit perusahaan manufaktur tahun 2013 adalah sebesar 3,0584 dengan standar deviasi sebesar 0,39791.

Nilai minimum opini audit adalah sebesar 0 sedangkan nilai maksimum opini audit adalah sebesar 1. Nilai rata-rata variabel opini audit perusahaan tahun 2013 sebesar 0,9927 dengan nilai standar deviasi sebesar 0,08544 .

Nilai minimum opini going concern adalah sebesar 0 sedangkan nilai maksimum going concern adalah sebesar 1. Nilai rata-rata variabel opini going concern perusahaan tahun 2013 sebesar 0,0146 dengan nilai standar deviasi sebesar 0,12038. 
Nilai minimum subsequent event adalah sebesar 0 sedangkan nilai maksimum subsequent event adalah sebesar 9. Nilai rata-rata subsequent event tahun 2013 adalah sebesar 1,0146 dengan nilai standar deviasi sebesar 1,87470 .

\subsection{Uji Asumsi Klasik}

\subsubsection{Uji Normalitas}

Hasil uji normalitas dengan menggunakan uji kolmogorov-smirnov dapat dilihat pada tabel 4.3 di bawah ini :

Tabel 1. Hasil Uji Kolmogorov-Smirnov

One-Sample Kolmogorov-Smirnov Test

\begin{tabular}{|ll|r|}
\hline & & $\begin{array}{c}\text { Unstandardize } \\
\mathrm{d} \text { Residual }\end{array}$ \\
\hline $\mathrm{N}$ & Mean & 137 \\
Normal Parameters ${ }^{\mathrm{a}, \mathrm{b}}$ & Std. Deviation & .0000000 \\
& Absolute & .11 .99535545 \\
Most Extreme & Positive & .088 \\
Differences & Negative & -.137 \\
Kolmogorov-Smirnov Z & & 1.604 \\
Asymp. Sig. (2-tailed) & & .012 \\
\hline
\end{tabular}

a. Test distribution is Normal.

b. Calculated from data.

Dari hasil uji kolmogorov-smirnov di atas, dihasilkan nilai Asymp. Sig. (2-tailed) sebesar 0,012. Hasil tersebut dapat disimpulkan bahwa data residual dalam model regresi ini tidak terdistribusi normal karena nilai Asymp. Sig. (2-tailed) di bawah 0,05.

Dari hasil tersebut maka perlu memperbaiki data agar memperoleh data yang terbaik untuk penelitian. Untuk memperoleh hasil terbaik maka dilakukan transformasi data agar data menjadi lebih normal dengan menghapus outlier (data yang menyimpang jauh dari rata-ratanya). Hasil uji normalitas setelah adanya penghapusan data dari outlier adalah sebagai berikut :

Tabel 2. Hasil Uji Normalitas Setelah Dihapus Outlier

One-Sample Kolmogorov-Smirnov Test 


\begin{tabular}{|ll|r|}
\hline & & $\begin{array}{c}\text { Unstandardized } \\
\text { Residual }\end{array}$ \\
\hline $\mathrm{N}$ & Mean & 124 \\
Normal Parameters ${ }^{\mathrm{a}, \mathrm{b}}$ & Std. Deviation & .0000000 \\
& Absolute & .10 .12733455 \\
Most Extreme & Positive & .072 \\
Differences & Negative & -.112 \\
Kolmogorov-Smirnov Z & & 1.246 \\
Asymp. Sig. (2-tailed) & & .090 \\
\hline
\end{tabular}

a. Test distribution is Normal.

b. Calculated from data.

Setelah melakukan dihasilkan nilai Asymp. Sig. (2-tailed) sebesar 0,090. Hasil tersebut dapat disimpulkan bahwa data residual dalam model regresi ini terdistribusi normal karena nilai Asymp. Sig. (2-tailed) di atas 0,05.

\subsubsection{Uji Multikolinieritas}

Uji multikolinieritas dilakukan dengan cara melihat nilai tolerance dan nilai VIF, jika nilai tolerance $>0,10$ dan nilai $\mathrm{VIF}<10$ maka tidak terjadi gejala multikolinieritas dalam model regresi tersebut. Hasil uji multikolinieritas dapat dilihat pada tabel 3 di bawah ini :

Tabel 3 Hasil Uji Multikolinieritas

Coefficients $^{\mathrm{a}}$

\begin{tabular}{|rr|r|r|}
\hline \multicolumn{2}{|l|}{ Model } & \multicolumn{2}{|c|}{ Collinearity Statistics } \\
\cline { 2 - 4 } & & Tolerance & \multicolumn{1}{c|}{ VIF } \\
\hline & DKSIZE & .812 & 1.232 \\
& KIND & .855 & 1.170 \\
& ACIND & .942 & 1.062 \\
& & .993 & 1.007 \\
& OPIN & &
\end{tabular}




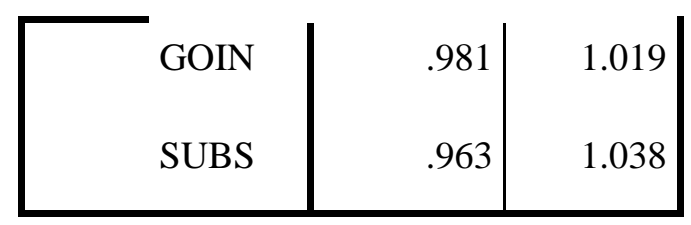

a. Dependent Variable: ARL

Dari hasil analisis uji multikolinieritas di atas, dihasilkan nilai tolerance $>0,1$ dan nilai VIF $<10$. Hasil tersebut dapat disimpulkan bahwa tidak terdapat masalah multikolinieritas dalam model regresi ini dan dapat digunakan untuk analisis selanjutnya.

\subsubsection{Uji Heteroskedastisitas}

Pengujian heteroskedastisitas dapat dilakukan dengan menggunakan grafik scatterplots, jika grafik terlihat titik-titik menyebar secara acak dan tersebar di atas maupun dibawah angka 0 sumbu Y maka tidak terjadi heteroskedastistas pada model regresi. Hasil uji heteroskedastisitas dapat dilihat pada Gambar 1 di bawah ini :

\section{Gambar 1. Hasil Uji Heteroskedastisitas}

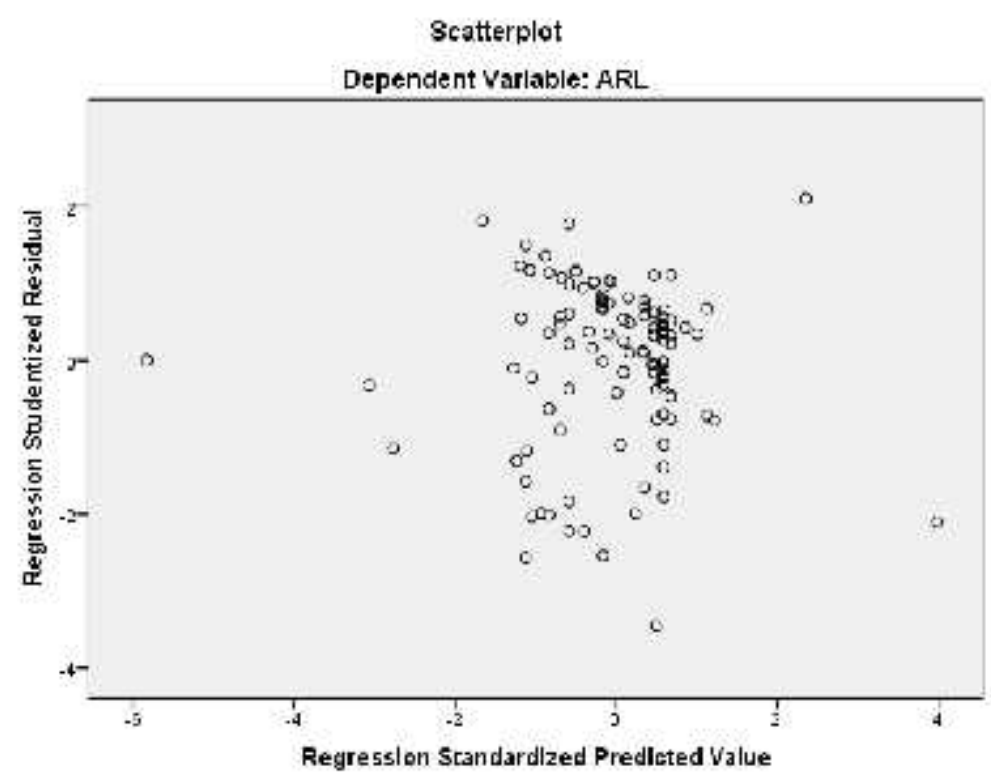

Dari hasil analisis uji heteroskedastisitas di atas, pada grafik scatterplot terlihat titik-titik menyebar secara acak dan tersebar di atas maupun dibawah angka 0 sumbu Y. Hasil tersebut dapat disimpulkan bahwa tidak terdapat gejala heteroskedastisitas dalam model regresi dan dapat digunakan untuk analisis selanjutnya.

\subsection{Hasil Pengujian Hipotesis}

Pengujian hipotesis dalam penelitian ini menggunakan uji statistic t. Hasil uji statistic t dapat dilihat pada tabel 4 
Tabel 4. Hasil Uji Hipotesis

\begin{tabular}{|c|c|c|c|c|c|}
\hline \multirow{3}{*}{ Variabel } & \multirow{2}{*}{\multicolumn{2}{|c|}{ Unstandardized Coefficients }} & \multicolumn{3}{|l|}{ Standardized } \\
\hline & & & Coefficients & $\mathrm{T}$ & Sig. \\
\hline & $\mathrm{B}$ & Std. Error & Beta & & \\
\hline DKSIZE & -3.233 & .882 & -.331 & -3.666 & .000 \\
\hline KIND & -5.478 & 4.327 & -.111 & -1.266 & .208 \\
\hline ACIND & -2.946 & 2.309 & -.107 & -1.276 & .204 \\
\hline OPIN & 35.297 & 10.464 & .275 & 3.373 & .001 \\
\hline GOIN & 18.707 & 7.473 & .205 & 2.503 & .014 \\
\hline SUBS & -.635 & .781 & -.067 & -.813 & .418 \\
\hline
\end{tabular}

Hasil pengujian hipotesis dalam penelitian ini memperoleh hasil bahwa ukuran dewan komisaris berpengaruh negatif signifikan terhadap audit report lag. Sedangkan komisaris independen tidak berpengaruh terhadap audit report lag perusahaan. Untuk variabel komite audit Independen disimpulkan bahwa komite audit independen tidak berpengaruh terhadap audit report lag.

Dalam variabel jenis opini yang diberikan auditor menunjukan bahwa, jenis opini yang diberikan oleh auditor berpengaruh positif signifikan terhadap audit report lag sehingga hipotesis keempat penelitian ini tidak dapat didukung. Kemudian variabel opini going concern berpengaruh positif signifikan terhadap audit report lag perusahaan. Dan variabel subsequent events ditemukan bahwa variabel ini tidak berpengaruh terhadap audit report lag.

\subsection{Pengaruh Ukuran Dewan Komisaris Terhadap Audit Report Lag}

Hasil penelitian ini membuktikan bahwa ukuran dewan komisaris berpengaruh negatif terhadap audit report lag. Dalam teori agensi (Jensen dan Meckling. 1976), dewan komisaris dianggap sebagai mekanisme pengendalian intern tertinggi yang bertanggung jawab untuk memonitor tindakan manajemen puncak. Semakin banyak jumlah anggota dewan komisaris dalam suatu perusahaan, maka fungsi monitoring terhadap kebijakan direksi dapat dijalankan dengan lebih baik, sehingga perusahaan akan terhindar dari berbagai macam bentuk kecurangan. Semakin besar jumlah anggota dewan komisaris, maka akan semakin mudah untuk mengendalikan CEO dan monitoring yang dilakukan akan semakin efektif sehingga pelaporan audit juga akan semakin cepat. 
Hasil penelitian ini tidak sejalan dengan Wardhani dan Surya (2013) yang menemukan bahwa ukuran dewan komisaris berpengaruh terhadap Audit Report Lag

\subsection{Pengaruh Komisaris Independen Terhadap Audit Report Lag}

Berdasarkan hasil analisis data di atas, dapat diketahui bahwa komisaris independen tidak berpengaruh terhadap audit report lag. Hasil penelitian ini disebabkan karena dewan komisaris independen dalam suatu manajemen hanya sebagai formalitas untuk memenuhi peraturan yang ditetapkan oleh pemerintah, tanpa mempertimbangkan efektivitas dan kompleksitas perusahaan. Hal tersebut juga didukung keputusan dalam menentukan jumlah anggota dewan komisaris khususnya komisaris independen yang tidak memperhatikan mengenai komposisi, kemampuan, dan integritas anggota sehingga dewan komisaris yang terpilih belum mampu memberikan arahan kepada manajemen dengan baik untuk mencapai transparasi dan penyusunan laporan keuangan yang berintegritas. Selain hal tersebut, pemegang saham mayoritas (pengendali/founders) masih memegang peranan penting sehingga menjadikan dewan komisaris tidak independen dan fungsi pengawasan yang seharusnya menjadi tanggung jawab anggota dewan menjadi tidak efektif. Hasil penelitian ini sesuai dengan penelitian yang dilakukan oleh Wardhani dan Surya (2013) yang menemukan komisaris independen tidak berpengaruh terhadap Audit report lag.

\subsection{Pengaruh Komite Audit Independen Terhadap Audit Report Lag}

Dari hasil analisis data diatas, dapat disimpulkan bahwa komite audit Independen tidak berpengaruh terhadap audit report lag. Hasil penelitian ini membuktikan bahwa peranan komite audit Independen tidak terlalu berjalan dengan baik. Komite audit Independen belum mampu bertanggung jawab untuk mengawasi laporan keuangan, mengawasi audit eksternal dan mengamati sistem pengendalian internal (termasuk audit internal). Komite audit Independen belum mampu memberikan kontribusi dalam kualitas pelaporan keuangan terutama kualitas laba. Komite audit Independen belum mampu meningkatkan integritas dan kredibilitas pelaporan keuangan melalui pengawasan atas proses pelaporan termasuk sistem pengendalian internal dan penggunaan prinsip akuntansi serta mengawasi proses audit secara keseluruhan. Hasilnya akan mengindikasikan bahwa adanya komite audit Independen belum memiliki konsekuensi pada laporan audit yaitu pelaporan yang cepat dan tepat.

Hasil penelitian ini sesuai dengan Wijaya (2012) yang menemukan bahwa Komite Audit Independen tidak berpengaruh terhadap Audit Report Lag dan tidak sesuai dengan penelitian Wardhani dan Surya (2013) yang menemukan bahwa Komite Audit Independen berpengaruh terhadap Audit Report Lag.

\subsection{Pengaruh Jenis Opini Auditor Terhadap Audit Report Lag}

Berdasarkan hasil analisis data diatas, dapat disimpulkan bahwa jenis opini auditor berpengaruh positif terhadap audit report lag. Perusahaan yang mendapatkan opini audit unqualified akan memiliki rentang audit report lag yang lebih lama daripada perusahaan yang mendapatkan opini selain unqualified. Fenomena ini dapat terjadi karena proses pemberian 
pendapat unqualified tersebut melibatkan negosiasi dengan klien, konsultasi dengan partner audit yang lebih senior atau staf teknis lainnya dan perluasan lingkup audit. Selain itu, auditor independen itu sendiri harus memiliki sikap hati-hati agar dapat mempertanggungjawabkan opini yang telah dibuat kepada pemakai laporan keuangan. Kehati-hatian tersebut juga dapat memperpanjang lamanya audit report lag. Hasil ini sesuai dengan penelitian Setyorini (2008) yang menemukan hasil opini auditor berpengaruh positif terhadap audit report lag.

\subsection{Pengaruh Opini Going Concern Terhadap Audit Report Lag}

Berdasarkan hasil analisis data diatas, dapat disimpulkan bahwa opini going concern berpengaruh positif terhadap audit report lag. Hasil ini membuktikan bahwa perusahaan yang diberikan opini audit going concern memiliki proses audit yang lebih panjang dibandingkan perusahaan yang tidak menerima opini going concern. Laporan auditor yang menunjukkan opini going concern memerlukan evaluasi secara eksplisit terhadap kemungkinan kelangsungan hidup perusahaan dalam setiap audit. Jadi, adanya kecenderungan penundaan dalam memulai proses audit. Sehingga dalam penentuan opini going concern, auditor dapat mengidentifikasi informasi mengenai kondisi atau peristiwa tertentu, jika dalam perimbangan menunjukkan adanya keraguan besar tentang kemampuan entitas dalam mempertahankan kelangsungan hidupnya dalam jangka waktu tertentu.. Hasil penelitian ini berbeda dengan penelitian Cecile (2010) yang menemukan hasil bahwa opini going concern tidak berpengaruh terhadap audit report lag.

\subsection{Pengaruh Subsequent Event terhadap Audit Report Lag}

Hasil penelitian ini membuktikan bahwa subsequent event tidak berpengaruh terhadap audit report lag. Subsequent event merupakan sejumlah transaksi atau beberapa peristiwa yang terjadi setelah tanggal neraca tetapi sebelum diterbitkannya laporan audit yang mempunyai akibat yang material terhadap laporan keuangan dan memerlukan penyesuaian atau pengungkapan dalam laporan tersebut. Penelaahan subsequent eventperlu dilakukan oleh auditor untuk menentukan apakah terjadi sesuatu yang mempengaruhi penilaian atau pengungkapan atas laporan keuangan yang sedang diaudit.

Hasil penelitian ini disebabkan karena masih rendahnya tingkat Subsequent event yang dialami oleh perusahaan sehingga tidak akan mempengaruhi rentang waktu pelaporan audit.

\section{KESIMPULAN}

Hasil dari statistik deskriptif menunjukkan bahwa rata-rata audit report lag tahun 2013 adalah 76,0146 hari. Hasil penelitian ini juga menunjukkan bahwa jenis opini auditor dan opini going concern berpengaruh terhadap Audit Report Lag. Selanjutnya, Ukuran Dewan Komisaris, Komisaris Independen, Komite Audit Independen dan Subsequent Event tidak berpengaruh terhadap Audit Report Lag 


\section{SARAN}

Untuk penelitian selanjutnya disarankan menambah sampel penelitian dengan jenis industri yang lain dan menambah periode penelitian sehingga diharapkan dapat menggeneralisasikan hasil penelitian. Penelitian selanjutnya diharapkan menambah variabel independen yang digunakan seperti menambah kepemilikan manajerial, kepemilikan institusional dan karakteristik komite audit. 


\section{DAFTAR PUSTAKA}

Barton dan Wong. Improving Board Performance in Emerging Markets. https://papers.ssrn.com/sol3/papers.cfm?abstract_id=899920.2006

Carslaw, C.A.P.N, dan Kaplan, S.E. "An Examination of Audit Delay : Further Evidence from New Zealand".Accounting and Bussiness Research. Vol 22. No.85, pp. 21 - 32 . 1991.

Cecile, Yovanca.. Pengaruh Debt to Total Asset Ratio, Kualitas Audit dan Opini Going Concern terhadap Audit Report Lag pada Perusahaan Manufaktur yang terdaftar di Bursa Efek Indonesia. Skripsi. 2010.Universitas Sumatera Utara

Darmawati, Deni, Corporate Governance dan Manajemen Laba: Suatu Studi Empiris, Jurnal Bisnis dan Akuntansi,Vol. 5, No. 1, April 2003,

Goodstein, Gautam, Boeker. The effects of board size and diversity on strategic change. Wiley Online Library. 1994. http://onlinelibrary.wiley.com/doi/10.1002/smj.4250150305

Hany, Clearly dan Mukhlasin,. Going Concern dan Opini Audit: Suatu Studi pada Perusahaan Perbankan di BEJ.Simposium Nasional Akuntansi VI. 1221-1233. 2003

Jensen, M. C. dan W. H. Meckling. Theory of the Firm: Managerial Behavior, Agency Cost and Ownership Structure. Journal of Financial Economics, Vol 3, 305-360. 1976.

Kirk, D. Experience with the Public Oversight Board and corporate audit committees. Accounting Horizons, Vol 14, 103-111. 2000.

Lianto,Novice dan Kusuma, Hartono Budi. Faktor-faktor yang berpengaruh terhadap Audit Report Lag. Jurnal Bisnis dan Akuntansi. Vol. 12, No.3, Hlm. 97-106. (2010).

Monks \& Minow. Corporate Governance. John Wiley and Son's. 2011. Ltd. Uk

Naimi, Mohammad et al.. Corporate Governance and Audit Report Lag in Malaysia. Asian Academy of Management journal of Accounting and Finance, Vol 6, 57-84. 2010

OECD, Principles of Corporate Governance. 2004. http://www.oecd.org/daf/ca/oecd-principlescorporate-governance-2004.htm

Porter, Michael E. Towards a dynamic theory of strategy. Wiley Online Library. http://onlinelibrary.wiley.com/doi/10.1002/smj.4250121008.1991

IAI, Pernyataan Standar Akuntansi Keuangan (PSAK). Salemba. Jakarta 2010.

Rachmawati, Sistya. Pengaruh Faktor Internal dan Eksternal Perusahaan terhadap Audit Delay dan Timesliness. Jurnal Akuntansi dan Keuangan, 10 (1) : 1-10. 2008.

Setyorini, Indah. Analisis Faktor-faktor yang Mempengaruhi Lamanya Penyelesaian Audit (Audit Delay) pada Perusahaan Publik di Indonesia. Skripsi. Universitas Brawijaya. Malang 2008.

Wardhani, Armania dan Raharja,Surya. Analisis Pengaruh Corporate Governance terhadap Audit Report Lag. Diponegoro Journal of Accounting, Vol 2, No.3 Hlm. 1. 2013

Wardhani, Ratna. Mekanisme Corporate Governance dalam Perusahaan yang Mengalami Permasalahan Keuangan. Jurnal Akuntansi dan Keuangan Indonesia. Vol.4, No.1, Hlm. 95-114. 2007.

Wijaya, A. T.. "Pengaruh Karakteristik Komite Audit terhadap Audit Report Lag". Skripsi . Fakultas Ekonomi. Universitas Diponegoro. Semarang. 2012. 